\title{
Ethical Leadership and Organizational Citizenship Behaviour: the Mediating Role of Ethical Climate, Trust, and Justice
}

\author{
Tayyaba Ahmed Fatima \\ Research Scholar \\ Karachi University Business School, University of Karachi, Pakistan \\ E-mail: tayyabarizve@gmail.com \\ Dr. Danish Ahmed Siddiqui \\ Associate Professor \\ Karachi University Business School, University of Karachi, Pakistan \\ E-mail: daanish79@hotmail.com
}

Received: Nov. 31, 2019 Accepted: Dec. 16, 2019 Online published: Dec. 16, 2019

doi:10.5296/ijhrs.v10i1.15954ＵRL: https://doi.org/10.5296/ijhrs.v10i1.15954

\begin{abstract}
This study analysed and showed that how the Top Managements' Ethical Leadership Influences Organization Citizenship Behaviour (OCB). We proposed that Ethical leadership affects OCB by promoting ethical climate and trust in an Organization. Thus, such factors gives a rise to Procedural Justice Climate and Distributive Justice, which resulted in OCB. This theoretical framework was empirically tested by gathering data of 210 employees who are working in different sectors in Pakistan by means of close ended Likert scale type questionnaires. Numerous statistical techniques for instance descriptive statistics, (CFA) confirmatory factor analysis and (SEM) structural equation modelling were used to analyse the results. As proposed in our theory, the results indicates a positive impact of Top Management Ethical Leadership on Ethical Climate and Trust in an Organization. Moreover, the result also indicates a significant positive impact of trust on both Procedural Justice Climate \& Distributive Justice. Furthermore, both of these completely intercedes the consequences of top management ethical leadership on organizational citizenship behaviour. From a different viewpoint, the impact of ethical climate on Procedural Justice Climate is
\end{abstract}


significantly positive, however; the relationship between ethical climate and Distributive Justice was found to be insignificant. Hence, this investigation provides a credible theoretical description as well as observed support of a contrivance through which ethical leadership of top management boosts Organizational Citizenship Behaviour. Therefore, managers in organization can rise Firm level OCB by enhancing the overall environment of the corporation and participatory factors in an ethical manner.

Keywords: ethical leadership, organization citizenship behaviour, ethical climate, trust in organization, procedural justice climate, distributive justice, pakistan, SEM

\section{Introduction}

\subsection{Background to the Study}

Ethical supervision of the senior level executives have emotional impact on employees' etiquette of middle-level management employees as such supervisors and workers (Mayer, Kuenzi, Greenbaum, Bardes, \& Salvador, 2009) therefore, the top-level directorate leadership's righteous facet should be taken as a primary element that impacts viability of the organization (Treviño, Brown, \& Hartman, 2003). Hence, understanding the job of moral headship in corporations is fragmented without understanding whether and how the top administration moral headship is related to institutional results in a longer run. To this end, the analysis by (Shin, Sung, Choi, \& Kim, 2014) explores the relationship between top administration moral headship \& the organizational viability. All the more explicitly, the study concentrated on two authoritative results, to be specific, the mutual (OCB) organizational citizenship behavior of workers and the enterprise monetary execution, that signify the social \& money related results of a corporation, individually.

We improve a hypothetical system to clarify the system on account of which the moral leadership of top directors produces positive hierarchical results. Here, we draw on formal theory (Scott, 1995), which places that institutional empowering influences (e.g. administration, hierarchical structure, and assets) impact the aggregate view of hierarchical individuals in forming results at the establishment level (Choi \& Chang, 2009).

Past individual-level researches show that chief moral conduct or ethical quality is well-suited to shape relating worker dispositions and convictions just as standards identified with moral benchmarks (Walumbwa \& Schaubroeck, 2009) (Dickson, Smith, Grojean, \& Ehrhart, 2001). Top administrators are able to make and keep up moral standards and atmosphere inside the firm (Schminke, Ambrose, \& Neubaum, 2005), and in this manner, the moral headship of top leadership may be in a positive way linked to the moral \& procedural equity atmospheres of association, that are responsible directly for firm-level organizational citizenship behavior. In spite of the fast advancement of this surge of investigation, diminutive has been thought about effect of moral administration on comprehended equity of organization amongst workers. Such oversight is astounding as justice is a basic worth and ideals inside an association (Rawls, 1971) and workers' comprehended equity towards their hiring association is firmly identified with their moral suspicions in regards to how people ought to be treated in the work environment (Loi, Lam, \& Chan, 2012). Moreover, the 
notable whistleblowing instance of Enron uncovers that when administrators act dishonestly, workers would inquire directors' ethnicity as well as inquire whether the association's strategies and procedure are appropriate or not (Premeaux, 2009). Hence, it is both hypothetically and basically critical to look at why and how moral administration conduct applies its impact on workers' equity perceptions toward their association.

Moreover, Past study has acknowledged trust as a significant force of distributive \& procedural equity (Tyler, 1994) (Hoy, Hoy, \& Tarter, 2004). The manner in which how chiefs carry on has been found to have noteworthy effect on commencing workers' faith (Whitener, Brodt, Korsgaard, \& Werner, 1998). The exploration by (Xu, Loi, \& Ngo, 2014) makes a stride ahead to research why \& how moral headship influences adherents' equity conceptions toward the corporation by investigating organizational trust as a principle hidden instrument. By tending to moral chiefs as distinctive ethical representatives of the corporation, the author contend that the activities exhibited by moral chiefs give a base to supporting workers' trust in their corporation, which thusly improves their assessments of institution-centered equity.

Past research studies have either focused on ethical atmosphere of the association or organizational trust while investigating the impact of moral leadership of the top management on Firm-level OCB. To fill the gap in this research study we have combined both models of (Shin, Sung, Choi, \& Kim, 2014) and (Xu, Loi, \& Ngo, 2014) and worked on the study while focusing both organizational ethical atmosphere and organizational trust keeping justice perception common.

\subsection{Gap Analysis}

Ethical governance is considered the most crucial characteristic of a corporate leadership (Michael E. Brown, 2005). However, the observed correlation, be it positive or negative, between moral headship of the higher management $\&$ the organization outcome in an organized way has not been tested later than common subjective affirmations (Treviño, Brown, \& Hartman, 2003). In the research (Shin, Sung, Choi, \& Kim, 2014), a Conceptual framework is developed and analytically tested in which the leadership of the top management forecasts the firm's outcome by determining the organization-level atmosphere related to moral management.

Many studies like (Lin, Che, \& Leung, 2009), (Pastoriza, Ariño, \& Ricart, 2007), (Neubert, 2009) affirm the essentialness of moral administrative conduct for employees results, for example, happiness, sense of duty, and citizenship practices but they center around supervisors or first-line administrators, as opposed to top administration. Past research on moral administration hardly analyzes the relationship and connecting instruments between top administration moral headship \& administrative accomplishment. The present alcove is a precarious oversight in light of fallouts that the higher level administration designs the righteous environment of an organization (Treviño, Butterfield, \& McCabe, 1998) along with the policies and procedures of the firm (Freeman, Gilbert, \& Hartman, 1988).

Earlier researches have been done individually on the impact of ethical leadership of top management on firm level OCB via Ethical Climate (EC) and Procedural Justice (PJ) and on 
the effect of moral leadership of higher management on firm-level OCB via trust in organization (OT) and Distributive Justice (DJ). To this note, these two topics were not combined with each other. To bridge this gap \& to point out the positive results out of these topics I have tried to connect these topics with each other.

The firm-level examination in Korea by (Shin, Sung, Choi, \& Kim, 2014) demonstrates that top administration moral initiative essentially predicts moral atmosphere, which at that point brings about procedural equity atmosphere that totally intercedes the effects of top administration moral authority on organizational results that is firm-level organizational citizenship behavior. The framework that has been proposed and tested for the study done by (Shin, Sung, Choi, \& Kim, 2014) shows that the moral leadership of top management backs outcomes of organization by stimulating firm level ethical climate and procedural justice climate.

(Xu, Loi, \& Ngo) Studied how and why the ethical leadership of top managers effects the perception of employees towards organization-focused equity that is procedural and distributive justice. The researchers build up the connection between moral headship and two type of equity in other words distributive justice \& procedural justice by offering moral heads as honest representatives of organization. Writers further suggests that trust in organization is the main mediation tool in the connection. Our outcomes show that moral initiative conduct causes workers' trust in their utilizing association, which thusly advances their equity discernments toward the association.

The limitations of the above mentioned studies includes the assessment of moral headship of higher management was done by higher management's heads' self-reports on moral views \& conducts. Likewise, the firm level (OCB) Organizational Citizenship Behavior was evaluated utilizing the collection of representative appraisals of individual level Organizational Citizenship Behavior (OCB). These methods could welcome inclinations, for example, social attractiveness. This gap is covered by collecting the data from over all employees working in different sectors operative in Pakistan, be it top manager, middle manager, lower manger or non-manager. Through this a clear and true representation of population and reliable data is collected.

Moreover, the data of (Xu, Loi, \& Ngo) was collected from only one industry of one Asian country. Whereas, present study focuses on all different sectors operative in Pakistan.

Furthermore, prior researches related to the impact of moral leadership of higher management on firm level OCB only focused on either moral atmosphere or organizational trust, one at a time. However, it is necessary to know the impact of both i.e. ethical climate (EC) and trust in organization (OT) collectively while investigating the effect of moral leadership of higher management on firm level organizational citizenship behavior.

\subsection{Research Objectives}

Present research study aims to examine the trend of ethical leadership in organizations in different sectors operative in Pakistan. This research study also aims to examine the impact of ethical leadership on firm-level OCB through evaluating impact of ethical climate, 
organizational trust, procedural equity climate $\&$ distributive equity in various organizations working in different sectors operative in Pakistan.

To this note the present study aims to combine the both prior (Shin, Sung, Choi, \& Kim, 2014) and (Xu, Loi, \& Ngo) studies' model and to gauge the impact of moral leadership of higher management on moral atmosphere and as well as on the trust in organization (OT). Moreover, this study investigates the effect of ethical climate on procedural justice (PJ) and on Distributive Justice (DJ). Present study further examines the impact of trust in organization (OT) on Procedural Justice (PJ) and on Distributive Justice (DJ). Finally, the current research study also inspects the significance of the impact of Procedural Justice (PJ) and Distributive Justice (DJ) on the firm-level Organization Citizenship Behavior (OCB).

Focusing on the gaps analyzed the present study aims to cover those gap and for this purpose the impact of moral headship of top managers has been examined on firm level Organizational Citizenship Behavior (OCB) while studying the effect of trust in organization, ethical climate, procedural and distributive justice climates in different sectors of Pakistan.

\subsection{Esearch Question}

1. What is the impact of Top management ethical leadership on ethical climate?

2. What is the impact of Top management ethical leadership on trust in organization?

3. Is there significant relationship between ethical climate and procedural justice climate?

4. Is there significant relationship between ethical climate and distributive justice?

5. Is there significant relationship between trust in organization and distributive justice?

6. Is there significant relationship between trust in organization and procedural justice climate?

7. Is there significant relationship between procedural justice climate and firm-level OCB?

8. Is there significant relationship between distributive justice climate and firm-level OCB?

\subsection{Significance}

Knowing the role of ethical atmosphere and organizational trust collectively is important because moral atmosphere and trust in organization are directly related to each other. Some proof exists demonstrating that workers will have a more noteworthy degree of trust when organizational chiefs are seen as having high uprightness and genuineness (FERRIN \& DIRKS, 2002) (Posner \& Schmidt, 1992) (Treviño, Brown, \& Hartman, 2003). In the light of above researches it can be assumed that the ethical climate of an organization has positive impact on trust in organization. Thus it is important to study the impact of both while investigating the effect of moral leadership of top management on firm-level organizational citizenship behavior (OCB). Knowing the impact of the ethical climate, trust in organization and justice would help the management and the organizations to have better workforce. The present study would benefit the managers or the leaders in shaping the organization's environment ethical. As we know, ethical climate in the organization would increase 
employees' organizational citizenship behavior and trust in organization positively. Present study would help the situations of the organizations in every sector operative in Pakistan, as the present study focuses on the impact of ethical practices of top management in an organization on employees' firm level OCB while focusing mediating effect of ethical climate, trust and justice. By shaping the environment of their organization ethical managers can get benefit in both performance and financial outcomes. This study would help managers and leaders to know the significance of ethical and trustworthy environment in the organization.

The present investigation would profit the supervisors or the pioneers in molding the association's condition moral. As we are aware, moral atmosphere in the association would build workers' organizational citizenship behavior and trust in association positively. Present investigation would help the circumstances of the associations in each area operative in Pakistan, as the present examination centers around the effect of moral practices of top administration in an association on workers' firm level OCB while centering interceding impact of moral atmosphere, trust and equity. By molding the environment of their association moral supervisors can get advantage in both execution and budgetary results. This investigation would support directors and pioneers to know the criticalness of moral and dependable condition in the association.

Different industries of the Pakistan need to know that impact of ethical leadership on firm-level OCB for the better ethical environment of the organization and also for better outcomes be it tangible or intangible than before. The data collected for the study shows a true and clear picture of the population as we tried keep it free of biasness by making all level of employees fill the questionnaire from various industries operative in Pakistan.

\section{Literature Review}

Ethical Leadership:

Ethical heads have been depicted by (Treviño, Hartman, \& Brown, 2000) as both "moral people" and "honest supervisors". The "ethical individual" aspect recognizes the inspirations furthermore, individual qualities of moral pioneers, described as caring, genuine, dependable, principled, convincing, and impartial (Brown, Treviño,, \& Harrison, 2005). In individual and professional lives both, moral heads are focused on taking measures dependent on moral choice principles. The "ethical administrator" aspect shows these pioneers set and convey moral norms and desires, not just design their very own practices and hierarchical procedures to fulfill the ethical standards, yet in addition proactively use rewards and control to consider supporters responsible for moral direct (Brown \& Mitchell, 2010).

According to the research done by (Shin, Sung, Choi, \& Kim, 2014), the hypothetical and exact improvements are insufficient, in spite of the common talks on the significance of top administration ethical headship. The research proposed that the ethical headship of the top management conduce to hierarchical results by advancing firm-level moral and procedural justice environment, drawing on institutional hypothesis. This hypothetical structure was observationally assessed utilizing multi-source information taken by 4,468 workers from 147 Korean organizations from different ventures. The firm-level examination demonstrated that 
top administration moral headship notably forecasts moral environment, which resulted in procedural virtue environment that completely intercedes the impacts of top administration moral headship on two organizational results, to be specific, firm-level hierarchical citizenship behavior and monetary outcome.

Utilizing information gathered at two stages, the investigation by (Xu, Loi, \& Ngo, 2014) inspects how \& why moral administration conduct impacts workers' assessments of association centered virtue, i.e., procedural justice and distributive virtue. Offering moral chiefs' as virtuous experts of the association, the author developed the linkage between moral headship conduct and the pre-mentioned two sorts of association-centered virtue. Authors further proposed trust in association as a key intervening instrument in linkage.

According to (Kaptein, 2019), moral authority has turned into a famous subject of observational research as of late. Most investigations pursue (Brown, Treviño,, \& Harrison, 2005) meaning of moral initiative, which comprises of two segments: the ethical individual and the ethical chief.

Ethical Climate:

According to (Martin \& Cullen, 2006) Moral climate alludes to mutual insight of workers on moral strategies, proceedings, and processes of association.

The literature review of (Brown \& Treviño, 2006) centers on the rising idea of moral headship and relates this idea with associated ideas that offer a typical affair for an ethical element of headship (e.g., reflective, legitimate, and transformational administration). Regardless of an expanding number of researches on moral environment (ethical climate), little is thought about the precursors of moral environment and the mediators of the connection between moral environment and work results. In the study done by (Shin \& Yuhyung, 2012) firm-level investigations with respect to the relationship between the moral headship of the chief executive officer (CEO) and moral environment, also the moderating impact of the strength of the climate (i.e., understanding in climate conception) on the connection between moral environment and shared organizational citizenship behaviour (OCB). Information of Self-report was gathered in South Korea from 6,021 workers and 223 CEOs. The outcomes encouraged all hypotheses of research. As anticipated, CEOs' self-appraised moral headship had a positive correlation with workers' collected view of the moral environment of the firm. The climate strength moderated the connection between moral environment and firm-level aggregate OCB. To be more precise, when the climate strength was high the relationships between moral climate and interpersonal focused aggregate OCB and between moral climate and organizationally focused aggregate OCB were more noticeable than when the climate strength was low.

(Mulki, Jaramillo, \& Locander, 2009) Investigated the kind of leadership technique that can serve organizations build up a moral environment. 333 number of responses were taken from the sales reps working for a subsidiary of international pharmaceutical organization in North America and were then utilize for the analysis of the impact influential leadership on moral climate. 


\section{Macrothink}

Depending on the Social Identity Approach, (Pagliaro, Presti, Barattucci, Giannella, \& Barreto, 2018) proposed that the impacts of various moral climates on worker's behaviour are driven by affective identification with institution/association along with, rational virtuous disengagement. They thought about the impacts of two specific moral climates acquired from the study: An organizational moral climate of personal interest and also an organizational moral climate of fellowship. Three hundred seventy-six (376) labourers finished evaluations of Moral Climate, Organizational Identification, Virtuous Disengagement, Organizational Citizenship Behaviours (OCBs), and Counterproductive Work Behaviours (CWBs). Structural equation modelling affirmed that the two moral climate measured were autonomously correlated with organizational identification and virtuous detachment. The measured two moral climates then intervened the impacts of moral climate on OCBs and Counterproductive Work Behaviours (CWBs).

(Yener, Yaldiran, \& Ergun, 2012), examined moral environment and work commitment ideas. The estimations have been assembled in a 53-element analysis and implemented to 199 workers of one of the greatest car producer situated in Bursa, Turkey. The outcomes demonstrate that work commitment is decidedly and fundamentally related with moral environment. Social obligation atmosphere greatly affects work commitment than different elements of moral environment. Social duty atmosphere's impact on commitment aspect of work commitment is more prominent than its impact on assimilation and strength aspect. Moral environment's association with devotion and adaptation is more grounded than its association with strength.

Trust in Organization:

According to Robinson (Robinson S. L., 1996), trust alludes to "individual's desires, presumptions, or else convictions concerning the probability that other's future activities will be useful, ideal, or possibly not inconvenient to individual's benefits".

(Singh \& Srivastava, 2016) investigated the connection between certain institutional-level elements, for example, as determining factor of trust in organization, perceived organizational support (POS), procedural equity and correspondence, and the effect of these factor on organizational citizenship behaviour (OCB). The information was gathered from top, middle and lower supervisory levels and the total number of respondents were three hundred and three (303), having a place with different organizations in assembling and administrations area. Standard scales were utilized to evaluate trust in organization (OT) and its precursor and subsequent variables. The outcomes demonstrated that precursor factors helped in improving the level of trust in organization (OT). As disclosed by the members of corporation, existence of trust in organization (OT) is perfectly connected with each components of OCB. Trust in organization as well, in part interceded the connection between the institutional standards variables and organizational citizenship behaviour (OCB).

This investigation (Wong, Wong, \& Ngo, 2012) analysed the connections between organizational equity, perceived organizational support (POS), trust in association and institutional citizenship conduct i.e. OCB by proposing three contending models and testing them. The standard model connects POS to distributive equity as its forerunner, and 
organizational trust to procedural equity as its predecessor, however the result of POS and organizational trust is viewed as organizational citizenship behaviour (OCB). Two elective models are created to test the impact of distributive equity on organizational trust (OT), and that of procedural equity on POS. In particular, they observed that distributive equity influences POS and procedural equity influences organizational trust (OT). POS has a huge constructive outcome on organizational trust (OT) and OCB.

(Tan \& Lim, 2009) The writers proposed an altered model of organizational trust that joins trust in 2 foci: peers and organizations. They found a connection between the 2 foci. The writers additionally found that trust in organization (OT) intervenes the connection between trust in colleagues and organizational results of effective commitment and execution. These discoveries recommend that it is important to look at the relations between other foci of trust to more readily see how various areas collaborate and how such trades in the long run lead to wanted hierarchical results.

Procedural Justice:

In recognizing various kinds of organizational equity, justice scholars (Colquitt, 2001) usually allude distributive equity to supposed equality in the allotment of hierarchical results, \& allude procedural equity to the apparent impartiality of procedure through which assets and results of organization are dispensed. As proposed by multi-foci equity study e.g. (Loi, Yang, \& Diefendorff, 2009) (Cropanzano, Prehar, \& Chen, 2002), as discussed above, 2 sorts of equity perception are viewed as organization-centred, as asset distribution decisions and rules for procedures are built up and constrained by the organization.

(Luria \& Yagil, 2008) Inspected the connection between moral climate and the reasonable treatment by a corporation of workers. The investigation by was led in 20 cafés, with one hundred and seventy-one (171) workers and one hundred and three (103) clients. Moral environment was observed to be linked with service execution which, thusly, was found to completely intercede the relationship of moral environment with consumer loyalty. Moral environment was likewise found to correspond in a positive manner with procedural equity. Our outcomes demonstrate the advantages of the moral message transferred through constant administrative practices in service businesses.

(Sert, Elçi, Uslu, \& Şener, 2014) Looked at the connection between hierarchical equity, moral climate and perceived business related Stress. They indicated by the discoveries from 915 workers, distributional and procedural equity has a substantial negative impact on business related pressure. As well as, moral environment likewise negatively affects business related pressure.

(Song, Kang, Shin, \& Kim, 2012) Analysed the effect of a corporation's procedural equity and transformational headship on workers' citizenship practices and the intervening impact of the transformational authority in Korean revenue driven business firms. An aggregate of two hundred and two (202) cases were gathered from one of the three major corporations in Korea and a sum of one hundred and eighty-two (182) reactions were utilized for analysis of data after the information screening process. The outcomes show that a corporation's 
procedural equity positively influences the two factors of transformational headship and workers' citizenship practices however the transformational headship positively influences workers' citizenship practices as well.

Distributive Justice:

The most seasoned hypothesis of distributive equity can be followed to Aristotle. In his Nicomachean Ethics, the pragmatist kept up that equity dissemination included "something proportionate," which was characterized as "uniformity of proportions" by him. (Adams, 1965) Revamping this thought, spoke to powerful value hypothesis of circulation equity with regards to social trade (Cropanzano, Bowen, \& Gilliland, 2007) which is demonstrated by the condition: Outcome1/Input1 = Outcome2/Input2.

Distributive equity is based on social exchange theory. As shown by the social exchange theory, every individual portion provides something profitable to the next portion and acquires something significant subsequently. For illustration, workers offer their learning, vision, abilities, and effort to their supervisors and they get remunerations or pay rates, rewards and other benefits subsequently. As researched by (Adams, 1965) at which degree workers see such trades (extent of result to enter) as reasonable or unjustifiable and how they react to perception of injustice (Poole, 2007). (Arslan, 2005) Noticed that representatives who make a similar commitment to the organization, think about the results they gotten to the ones their associates get. For example, envision two representatives who put in a similar measure of vitality for comparative occupations. It is normal that they be paid a similar sum for their endeavours. On the off chance that one works multiple times harder than the other, at that point the harder specialist is relied upon to be paid multiple times more in contrast with the partner who works less.

View of distributive equity are significant for associations as a result of their impacts on various hierarchical results, for example, execution, responsibility, work fulfilment, authoritative citizenship conduct; and turnover goals (Flint \& Haley, 2013)

Firm-Level OCB:

OCB is the "individual conduct that is optional, not straightforwardly or unequivocally perceived by the formal reward frameworks, and that in the total advances the successful working of the organization (Organ, 1988).

The examination by (Vuuren, Dhurup, \& Joubert, 2016) explored workers' conception of institutional equity and their impacts on Organizational Citizenship Behaviour (OCB) at the SAPS Foundation, Paarl, South Africa. Utilizing a quantitative research model and an exploratory research technique, through an organized survey two hundred and twenty-six (226) workers were inspected. The relationship investigation disclosed that all three elements of institutional equity are connected altogether and emphatically to institutional citizenship conduct. Organizational equity demonstrated a solid prescient association with institutional citizenship conduct, by regression analysis. The investigation exhibited that workers demonstrate a more prominent inclination to take part in institutional citizenship conduct i.e. OCB when they can structure positive impression of procedural justice, distributive justice \& 
interactional equity.

(Smith, Organ, \& Near, 1983) Discussed that a classification of execution called citizenship conduct is significant in organizations and not effectively clarified by similar motivating forces that initiate section, adjustment to legally binding job remedies, or high generation. Information were gathered from 422 workers and their administrators from 58 divisions of 2 banks to look at the nature and indicators of citizenship conduct. Results propose that citizenship conduct incorporates at any rate 2 Aspects: humanity, or helping explicit people, and overall compliance, an increasingly generic type of principled citizenship. Employment fulfilment, as a proportion of constant temperament state, demonstrated a direct prescient way to philanthropy yet not overall compliance. Rural background directly affected the two components of citizenship conduct. The prescient intensity of different factors (e.g., pioneer steadiness as surveyed autonomously by colleagues and extraversion and neuroticism as evaluated by the Maudsley Personality Inventory) changed over the 2 elements of citizenship conduct.

(Rioux \& Penner, 2001) This examination focused on the job of thought processes in organizational citizenship behaviour (OCB). Three thought processes were recognized through factor examinations: prosocial values, authoritative concern, and impression management. Scales that evaluated these thought processes and different factors known to covary with OCB were controlled to 141 metropolitan workers and were connected with self-companion, and administrator evaluations of 5 parts of OCB. In respect to different thought processes, prosocial values intentions were most firmly connected with OCB coordinated at people, and organizational concern thought processes were most emphatically connected with OCB coordinated toward the association. Every one of the thought processes represented remarkable measures of fluctuation in OCB. The outcomes propose that thought processes may assume a significant job in OCB. 


\section{Conceptual Framework}

\subsection{The Study Model}

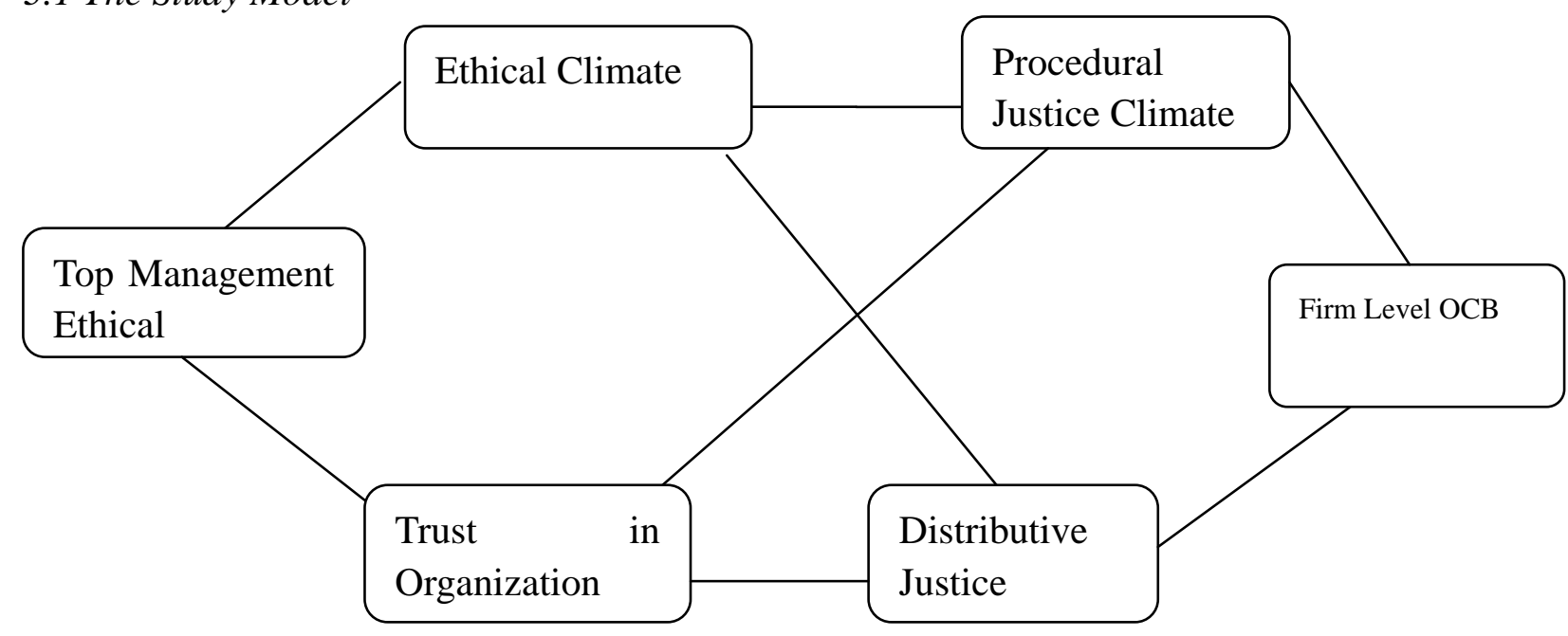

Top Management Ethical Leadership and Ethical Climate:

Ethical climate speaks to the general view of workers of the ethicality of the approaches, systems, and practices of the association, though procedural equity climate is a smaller type of organizational environment related to the reasonableness of business related choices and asset assignment forms in the association. Of the two sorts of climates, moral atmosphere is a progressively conventional type of organizational environment that is legitimately influenced by top administration moral authority. Top management moral headship is a key factor in shaping a moral organizational environment and advancing moral work conduct (Carlson \& Perrewe, 1995) (Posner \& Schmidt, 1992). At the point when workers respect top supervisors as the delegate specialists of the association (Eisenberger, et al., 2010), they decipher moral qualities and practices of top supervisors as the prompts of the moral direction of the organization, and this translation influences the development of a moral atmosphere inside the firm (Dickson, Smith, Grojean, \& Ehrhart, 2001).

Top Management Ethical Leadership and Trust in Organization:

Workers' trust in association is a fundamental element for a stable worker-association relationship (Cook \& Wall, 1980). Such view is reliable with the social exchange theory (Blau, 1964), which features the part of trust in the rise and upkeep of a long haul work relationship. At the point when workers have more trust in their organization, they would accept that a social exchange relationship with the association has been created, and they are slanted to have inspirational assumptions regarding the words, activities, thought processes, and choices of the organization.

Moral heads stand out as the ethical specialists demonstrating the organization in managing work relationships with workers. Consequently, it is normal for workers to interpret the manner in which moral pioneers carry on and treat others as beginning from the association. Expanding on this rationale, we contend that moral leadership conduct, perceived by workers as following up in the interest of the organization, will encourage workers' trust in 
organization. In particular, moral heads encourage organizational objectives and interests among workers continuously over time and crosswise over circumstances. Plus, they create and exhibit certified apprehension for the welfare of workers (Treviño, Brown, \& Hartman, 2003) for the sake of the association. They additionally include workers in decision-making practices of the organization (Kalshoven, Den Hartog, \& De Hoogh, 2012), and proactively and transparently convey authoritative (moral) desires (Brown \& Mitchell, 2010). Seemingly, all these are the structure obstructs for creating workers' trust in association (Robinson \& Rousseau, 1994).

Ethical Climate and Procedural Justice Climate:

The firm-level moral climate moulded by top administration moral authority further gives a setting where explicit task-related decisions and activities dependent on the standard of reasonableness are encouraged. That is, when workers see a high level of moral atmosphere, they will in general highlight the impartiality and clearness in making different asset allotment decisions (Naumann \& Bennett, 2000). Subsequently, an increasingly explicit type of organizational atmosphere identified with procedural equity is probably going to develop in organizations with a moral atmosphere. Albeit inadequate and for the most part at the person level, earlier research has commonly shown a positive relationship among moral and procedural equity atmosphere (Luria \& Yagil, 2008) (Treviño \& Weaver, 2001). Maybe, the profound quality and moral standards supported and pursued by the organization, and its individuals could influence the mutual impression of employees of procedural equity (Cropanzano, Goldman, \& Folger, 2003). Workers will in general see decision making processes as judicious when they feel that the exercises and works inside their organization are performed dependent on moral and moral standards.

Ethical Climate and Distributive Justice:

As defined by (Martin \& Cullen, 2006) ethical climate is joint opinions of workers on the moral strategies, practices, and processes of the organization. Whereas, (Colquitt, 2001) defined distributive justice as supposed fairness in the allotment of organizational results. On the basis of above mentioned concept of ethical climate and distributive justice we can understand that when an organization works in an ethical way which means makes its strategies, policies and procedure in an ethical way the perception of the employees towards organization and organizational goodwill develops in a positive manner. Which indicates that the employees of the organization feel and believe that the organizational outcomes are being distributed amongst all equitably.

Trust in Organization and Distributive Justice:

The method for utilizing contingent reward to help moral direct is predictable with adherents' view of distributive equity. Trust in association is basic for creating distributive justice since it can fortify the impression of equity for workers (Tan \& Tan, 2000). At the point when individuals create trust in organization dependent on moral headship conduct, they will show positive stance and discernments toward the organization (Dirks \& Ferrin, 2001). For whatever length of time that workers trust their employing association, they are probably 
going to have a solid inclination that it would serve their best advantages. Therefore, they will in general accept that the organization will adjust the assets or prizes dependent on their assistances over time (Konovsky \& Pugh, 1994). Past research has given proof that trust altogether moulded distributive equity impression of workers (Mansour-Cole \& Scott, 1998) (Tyler, 1989) (Tyler, 1994).

Trust in Organization and Procedural Justice Climate:

As featured by (Bal, De Lange, Ybema, Jansen, \& Van Der Velde, 2011), trust in association assumes a focal job in procedural equity assessment in the working environment. At the point when workers build up their trust in company dependent on moral authority conduct, they would hold positive inclination with respect to the thought processes and expectations of the association (Tyler, 1994). Furthermore, they may have a solid conviction that they would not be exploited (Pillai, Schriesheim, \& Williams, 1999), and subsequently they will in general assess the organization strategy and practices in a positive way (Wong, Wong, \& Ngo, 2012). Extant writing has reliably demonstrated that trust was a critical indicator of procedural equity (e.g., (Hoy, Hoy, \& Tarter, 2004), (Lind, Tyler, \& Huo, 1997).

Procedural Justice Climate and Firm-Level Organizational Citizenship:

Procedural justice climate is a particular type of organizational climate that mirrors the view of representatives of decency in their day by day assignments and exercises, and along these lines, this kind of atmosphere is probably going to influence firm-level OCB and money related outcomes directly. Past investigations (Ehrhart M. G., 2004) and (Walumbwa, Hartnell, \& Oke, 2010) illustrate the positive connection between procedural justice climate and firm-level OCB at the group level. We anticipate a comparable relationship at the firm level for a few reasons. In the first place, the group value and social models of procedural equity place that judicious organizational processes signal workers that they are esteemed by their pioneers and the association. Subsequently, the workers take part in Organizational Citizenship Behaviour (OCB) to keep up and to upgrade positive mental advantages that come from relating to their pioneer and the organization (Tyler, \& Blader, 2003).Secondly, the fairness heuristics theory states that people depend on impartiality decisions when they choose whether to carry on for their self-interest or to help other people (Lind, 2001). Accordingly, workers are almost certain to take part in a prosocial conduct when they see a high level of fairness in their association. At last, the collective social exchange theory (Gong, Chang, \& Cheung, 2010) recommends that when workers see just treatment, shared observations inside the firm raise the regulating level of aggregate OCB, which results in a high state of OCB of the firm.

Distributive Justice and Firm-Level Organizational Citizenship:

As defined by (Organ, 1988) OCB is defined as "individual behaviour that is optional, not straightforwardly or unambiguously perceived by the formal reward frameworks, and that in the total enhances the successful working of the organization. On the basis of above mentioned concept we propose a positive relation between distributive justice and firm-level OCB because the perceived fairness in allocation of resources will eventually lead to 
increased firm-level OCB.

\subsection{Hypothesis}

H1: Top management ethical leadership is positively related to ethical climate.

H2: Top management ethical leadership is positively related to trust in organization.

H3: Ethical climate has significant relationship with procedural justice climate.

H4: Ethical climate has significant relationship with distributive justice.

H5: Trust in organization has significant relationship with distributive justice.

H6: Trust in organization has significant relationship with procedural justice climate.

H7: Procedural justice climate has significant relationship with firm level OCB.

H8: Distributive justice climate has significant relationship with firm level OCB.

\section{Methodology}

The sample of the study is comprising either genders. It includes employees and managers at all institutional levels considering various companies in different sectors operative in Pakistan. The prepared questionnaire targets managers and employees at all levels of organization, in various sectors of Pakistan. The non-probability sampling techniques was adopted for the present study. Descriptive statistic is used to analyse the responses of the questionnaire. Confirmatory factor analysis (CFA) and structural equation modelling (SEM) were used for inference.

\subsection{Sampling}

The sample size of this study was 210 employees working in different sectors operative in Pakistan and for the research purpose we successfully gathered required amount of responses from employees in various sector operative in Pakistan. As (Zikmund, Babin, Carr, \& Griffin, 2012) recommended, the method which is based on ease and self-judgemental units is knows as non-probability method of sampling. So on the basis of the above mentioned explanation, to gather our study sampling non- probability method of sampling is adopted.

\subsection{Research Design}

The 4 questions related to ethical leadership were adopted from (Brown, Treviño,, \& Harrison, 2005). We adopted the 2 questions related to ethical climate from (Treviño, Butterfield, \& McCabe). The first three questions of procedural justice were adopted from (Ehrhart M. G., 2004) and (Walumbwa, Hartnell, \& Oke, 2010) the fourth question of procedural justice was adopted from (Moorman, 1991). The 5 questions related to trust in organization were adopted from (Robinson, 1996). The 5 questions related to distributive justice were adopted from (Tang \& Sarsfield-Baldwin, 1996). And 2 questions related to firm level OCB were adopted from (Ehrhart M. G., 2004), (Mayer, Kuenzi, Greenbaum, Bardes, \& Salvador, 2009) and (Walumbwa, Hartnell, \& Oke, 2010). 
4.3 Demographic Analysis

Table 1. Frequency distribution

\begin{tabular}{|c|c|c|}
\hline Variable & Options & Percentage \\
\hline \multirow[t]{5}{*}{ Age } & $18-26$ Years & $35.7 \%$ \\
\hline & $27-35$ Years & $41.4 \%$ \\
\hline & $36-44$ Years & $13.8 \%$ \\
\hline & $45-53$ Years & $5.7 \%$ \\
\hline & 53 Years \& Onwards & $3.3 \%$ \\
\hline \multirow[t]{2}{*}{ Gender } & Male & $75.7 \%$ \\
\hline & Female & $24.3 \%$ \\
\hline \multirow[t]{5}{*}{ Tenure } & $0-1$ Years & $12.4 \%$ \\
\hline & $2-4$ Years & $34.8 \%$ \\
\hline & $5-7$ Years & $19 \%$ \\
\hline & $8-10$ Years & $12.4 \%$ \\
\hline & More than 10 years. & $21.4 \%$ \\
\hline \multirow[t]{4}{*}{ Employment Level } & Top Management & $13.3 \%$ \\
\hline & Middle Management & $56.2 \%$ \\
\hline & Lower Management & $22.9 \%$ \\
\hline & Non - Management & $7.6 \%$ \\
\hline \multirow[t]{3}{*}{ Industry Of Organization } & Banking & $14.3 \%$ \\
\hline & Manufacturing & $9.5 \%$ \\
\hline & Telecommunication & $13.8 \%$ \\
\hline
\end{tabular}




\begin{tabular}{|l|l|l|}
\hline & Textile & $4.8 \%$ \\
\hline & Software & $6.2 \%$ \\
\hline & Food & $2.9 \%$ \\
\hline & Others & $48.5 \%$ \\
\hline
\end{tabular}

The table no. 1 Frequency distribution indicates that $35.7 \%$ of the respondents are in the age limit of $18-26$ years, $41.4 \%$ of the respondents are of $27-35$ years of age, $13.8 \%$ lies between the age limit of $36-44$ years, $5.7 \%$ respondents' age limit is $45-53$ years, whereas, $3.3 \%$ respondents' come under the limit of 53 years and onwards. The table no. 1 also indicates the gender of the respondents. $75.7 \%$ of the respondents are male and $24.3 \%$ are female. The frequency distribution table further shows the tenure of employment of the respondents. $12.4 \%$ of the respondents' have $0-1$ years working experience, $34.8 \%$ respondents have $2-4$ years' tenure of employment, $19 \%$ respondents' tenure of employment is $5-7$ years, $12.4 \%$ of the respondents' employment tenure is $8-10$ years and $21.4 \%$ respondents' tenure of employment is more than 10 years. Table no. 1 indicates the employment level of the respondents. $13.3 \%$ respondents are of top management level, $56.2 \%$ respondents are of middle management, $22.9 \%$ respondents are of lower management and 7.6\% respondents are of non-management level. The frequency distribution table furthermore indicates the industry of the respondents. $14.3 \%$ respondents work in banking sector of Pakistan, $9.5 \%$ respondents are of manufacturing industry, $13.8 \%$ of the respondents serves the telecommunication sector of Pakistan, $4.8 \%$ respondents work in textile sector of Pakistan, $6.2 \%$ respondents are in software industry operative in Pakistan, $2.9 \%$ respondents are in food sector of Pakistan and $48.5 \%$ of the respondents work in various other sectors operative in Pakistan.

\subsection{Descriptive Statistic}

Table 2. Descriptive Statistics

\begin{tabular}{|l|l|l|}
\hline Questions & Mean & S.D \\
\hline Ethical Leadership: & & \\
\hline I discuss values and business ethics with employees. & 1.995 & 1.012 \\
\hline In terms of ethics I set an example of how to do things the right way. & 1.243 & 0.429 \\
\hline The best interests of employees in making decision is taken into account. & 2.248 & 0.778 \\
\hline $\begin{array}{l}\text { Success not just defined by the result but also the process through which } \\
\text { they were achieved. }\end{array}$ & 4.798 & 2.385 \\
\hline
\end{tabular}




\begin{tabular}{|c|c|c|}
\hline Ethical Climate: & & \\
\hline $\begin{array}{l}\text { As prescribed by the company, employees in our company are expected to } \\
\text { follow to ethical rules and procedures. }\end{array}$ & 4.148 & 0.745 \\
\hline $\begin{array}{l}\text { Over and above any consideration, employees in our company are } \\
\text { expected to obey with the law and professional standards. }\end{array}$ & 4.224 & 0.745 \\
\hline Procedural Justice: & & \\
\hline $\begin{array}{l}\text { In accordance with clear rules and standards, decisions are taken in my } \\
\text { organization. }\end{array}$ & 3.929 & 0.900 \\
\hline Based on consistent procedures, decisions are taken in my organization. & 3.895 & 0.798 \\
\hline $\begin{array}{l}\text { Free of biased views and professional interest, decisions are taken in my } \\
\text { organization. }\end{array}$ & 3.819 & 0.964 \\
\hline $\begin{array}{l}\text { In my organization, procedures are designed to collect accurate } \\
\text { information necessary for making performance appraisal. }\end{array}$ & 3.776 & 0.957 \\
\hline Trust in Organization: & & \\
\hline I believe that my employer has high integrity. & 3.910 & 0.865 \\
\hline $\begin{array}{l}\text { I can expect my employer to treat me in a consistent and predictable } \\
\text { manner. }\end{array}$ & 3.900 & 0.848 \\
\hline In general, I believe that motives and intentions of my employer are good. & 3.952 & 0.785 \\
\hline I think that my employer treats me fairly. & 3.705 & 0.930 \\
\hline $\begin{array}{l}\text { I am being treated openly and upfront by the managers of my } \\
\text { organization. }\end{array}$ & 3.857 & 0.940 \\
\hline Distributive Justice: & & \\
\hline $\begin{array}{l}\text { In rewarding, my organization have always been fair when considered the } \\
\text { amount of effort that I have put forth? }\end{array}$ & 3.581 & 1.085 \\
\hline $\begin{array}{l}\text { In rewarding, my organization have always been fair when considered the } \\
\text { responsibilities that I have. }\end{array}$ & 3.638 & 1.025 \\
\hline $\begin{array}{l}\text { In rewarding, my organization have always been fair when considering the } \\
\text { stresses and strains of my job? }\end{array}$ & 3.538 & 0.996 \\
\hline $\begin{array}{l}\text { In rewarding, my organization have always been fair when considering the } \\
\text { amount of education and training that I have? }\end{array}$ & 3.505 & 1.052 \\
\hline
\end{tabular}




\begin{tabular}{|c|c|c|}
\hline $\begin{array}{l}\text { In rewarding, my organization have always been fair when considered the } \\
\text { work that I have done well. }\end{array}$ & 3.610 & 1.069 \\
\hline Firm - level OCB: & & \\
\hline I do not complain about the company outside. & 3.890 & 1.020 \\
\hline $\begin{array}{l}\text { When nobody is watching, I still comply with company rules and } \\
\text { regulations. }\end{array}$ & 4.138 & 0.831 \\
\hline
\end{tabular}

The table No. 3 indicates the items related to Ethical Leadership mean scores lies between the range of 1.995 - 4.798 while the standard deviation of the items related to Ethical Leadership lies between 0.429 - 3.829. Items related to Ethical Climate (EC) has mean scores of 4.148 and 4.224 while the standard deviations of the items of ethical climate are 0.745 each. The overall mean values are above than average it posits responses are more closely towards "strongly agree" at five point Likert scale. The table also indicates the mean scores of the items related to Procedural Justice (PJ) that is ranging between 3.776 - 3.929 and the standard deviation of the same range between $0.798-0.964$. The overall mean values are above than average it posits responses are more closely towards "strongly agree" at five point Likert scale. Furthermore, the Descriptive Statistic table shows the mean value of the items related to Trust in Organization (OT) that range between $3.705-3.952$ and the standard deviation of the items related to Trust in Organization (OT) ranges between $0.785-0.940$. The overall mean values are above than average it posits responses are more closely towards "strongly agree" at five point Likert scale. The table also shows mean values of items related to Distributive Justice (DJ) that is from 3.505 - 3.638 while the standard deviation of the items related to Distributive Justice (DJ) are from 0.996 - 1.085. The overall mean values are above than average it posits responses are more closely towards "strongly agree" at five point Likert scale. Table no. 3 shows the mean values of Firm - level Organizational Citizenship Behavior, the values of means are 3.890 and 4.138 while the standard deviation of the Firm-level Organizational Citizenship Behavior are 1.020 and 0.831 .

\section{Structural Equation Modeling}

To test the hypothesis of the present study, we have utilized the structural equation model (SEM) while the analysis has been done through the software Smart PLS. Furthermore, the analysis was done to analyse the direct and indirect effects of all the hypotheses. The utilization of structural equation model (SEM) has been perceived to be a leading procedure that has been utilized below various regression models and methods (Barron \& Kenny, 1986). It used to analyse the structural relation among exogenous and endogenous factors. It comprises factor analysis and multivariate analysis. In addition, the equation of regression focuses at clarifying every individual construct to measure the cause and effect relationship while all of the factors in the causal model could demonstrate their cause and effect at exact time. Similarly, the idea of utilizing this model ensures to apply bootstrapping technique which has been viewed as reasonable for both sample size small and large and does not require any kind of indirect effect (Hayes, 2103). In order to check the all direct and indirect 
effects, a technique has been implemented which is known as bootstrapping (Shrout \& Bolger, 2002).

\section{Measurement of Outer Model:}

The objective of measure of fit in the measurement model is to study about the dependability and legitimacy of the instrument and to check its consistency and validity we have performed test of convergent validity and discriminant validity in software naming Smart PLS.

Composite Reliability:

Reliability implies stability of questionnaire outcomes. For the similar target population, at whatever point the questioner reutilize the questionnaire it will give similar outcome. It demonstrates inside consistency \& repeatability of the survey is high. The primary measure for unwavering quality is to maintain a strategic distance from unfairness in research. In this manner, it tends to be improved by testing the pursuit procedure and investigation, as is done utilizing diverse research and examination techniques or different researchers. This also incorporates the dependability and legitimacy of the exploration.

Reliability of the measurement instruments was evaluated using composite reliability. All the values were above the normally used threshold value i.e. 0.70 . This is the accepted reliability value range. Estimation of reliability can be done by degree of constancy that lies amongst various variables (Hair , 2010). Below is the table of composite reliability.

Table 3. Reliability Statistics

\begin{tabular}{|l|l|l|l|}
\hline Measures & No. of items & Cronbach Alpha \\
\hline Ethical Leadership & 5 & 0.795 \\
\hline Ethical Climate & 2 & 0.681 \\
\hline Procedural Justice & 4 & 0.789 \\
\hline Trust in Organization & 5 & 0.835 \\
\hline $\begin{array}{l}\text { Distributive Justice } \\
\text { Organizational } \\
\text { Bitizenship }\end{array}$ & 5 & 2 & 0.928 \\
\hline
\end{tabular}

The data in table no. 2 Reliability statistic is significantly reliable as all the measures' reliability is above 0.7. the reliability value of Ethical Leadership (EL) is 0.795 that is greater than 0.7 making it significantly reliable, the reliability value of Procedural Justice (PJ) is 0.789 that is greater than 0.7 providing it reliability, reliability value of Trust in Organization (OT) is 0.835 which is greater than 0.7 indicating its significant reliability, the reliability value of Distributive Justice (DJ) 0.928 that is greater than 0.7 providing it exceptionally 
significant reliability. Except of the ethical climate, which is 0.681 and that is considered reliable according to (Hair, Black, Babin, \& Anderson, 2010) It states that the 0.6 value of reliability is acceptable for an exploratory research but it will be considered as lower value (underestimate).

Factor loadings significant:

Below is the mentioned table of (CFA) confirmatory factor analysis with the loadings. Construct with the loading of 0.5 are consider as strong loading variables whereas the constructs with the loading of below 0.5 are considered as less are better to be removed from the table.

Table 4. Confirmatory Factor Analysis

\begin{tabular}{|c|c|c|c|c|c|c|}
\hline $\begin{array}{l}\text { Factor } \\
\text { Loading }\end{array}$ & $\begin{array}{l}\text { Distributive } \\
\text { Justice }\end{array}$ & $\begin{array}{l}\text { Ethical } \\
\text { Climate }\end{array}$ & $\begin{array}{l}\text { Firm } \\
\text { Level } \\
\text { OCB }\end{array}$ & $\begin{array}{l}\text { Procedural } \\
\text { Justice }\end{array}$ & $\begin{array}{l}\text { Top Management } \\
\text { Ethical Leader }\end{array}$ & $\begin{array}{l}\text { Trust in } \\
\text { Organization }\end{array}$ \\
\hline DJ1 & 0.891 & & & & & \\
\hline DJ2 & 0.913 & & & & & \\
\hline DJ3 & 0.885 & & & & & \\
\hline DJ4 & 0.828 & & & & & \\
\hline DJ5 & 0.892 & & & & & \\
\hline $\mathrm{EC} 1$ & & 0.853 & & & & \\
\hline $\mathrm{EC} 2$ & & 0.887 & & & & \\
\hline EL1 & & & & & 0.781 & \\
\hline EL2 & & & & & 0.835 & \\
\hline EL4 & & & & & 0.777 & \\
\hline EL5 & & & & & 0.717 & \\
\hline OCB3 & & & 0.870 & & & \\
\hline OCB4 & & & 0.677 & & & \\
\hline
\end{tabular}




\section{Macrothink}

International Journal of Human Resource Studies

ISSN 2162-3058 2020, Vol. 10, No. 1

\begin{tabular}{|c|c|c|}
\hline PJ1 & 0.800 & \\
\hline $\mathrm{PJ} 2$ & 0.752 & \\
\hline PJ3 & 0.793 & \\
\hline PJ4 & 0.783 & \\
\hline $\mathrm{T} 1$ & & 0.780 \\
\hline $\mathrm{T} 2$ & & 0.764 \\
\hline T3 & & 0.826 \\
\hline $\mathrm{T} 4$ & & 0.810 \\
\hline T5 & & 0.713 \\
\hline
\end{tabular}

In the above table no. 4 it is indicated that five (5) indicator related to Distributive Justice (DJ) loading values are above 0.50 making them reliable and no value was needed to be eliminated. The table further shows that three (3) indicators of Ethical Climate (EC) has loading values more than 0.5 which means the indicators are reliable while one of the indicator i.e. EC3 is eradicated because of loading that is irrespective. Moreover, the table shows the five (5) indicators of Ethical Leadership (EL) has loading values over 0.5 whereas, the indicator EL3 is removed because of loading that is found irrespective. The table also shows the four (4) indicators of Firm - level Organizational citizenship behaviour (OCB) indicated the loading value over 0.5 while 2 indicators that is OCB 1 and OCB2 was eradicated because of loading that is found irrespective. The table no. 4 Confirmatory Factor Analysis indicated the loading value of the four (4) indicators of Procedural Justice (PJ) above 0.5 whereas, there was no need to eliminate any of the indicator. The table also shows indicated the loading value of the five (5) indicators of Trust in Organization (OT) above 0.5 whereas, there was no need to eliminate any of the indicator.

Convergent Validity:

Convergent validity is the degree of agreement in at least two measures of a similar construct (Carmines \& Zeller, 1979). Convergent validity was judged by assessment of variance mined for every individual element (Fornell \& Larcker, 1981). Consulting to (Fornell \& Larcker, 1981 ), if the, extracted value of the variance is greater than 0.5 then convergent validity is initiated and the outcome is drawn that the loadings are good but less than 0.5 are characterized as less effective for the research. 
Following table shows the outcomes.

Table 5. Construct Reliability \& Validity

\begin{tabular}{|l|l|l|l|l|}
\hline Matrix & $\begin{array}{l}\text { Cronbach's } \\
\text { Alpha }\end{array}$ & rho_A & $\begin{array}{l}\text { Composite } \\
\text { Reliability }\end{array}$ & $\begin{array}{l}\text { Average Variance } \\
\text { Extracted (AVE) }\end{array}$ \\
\hline Distributive Justice & 0.929 & 0.932 & 0.946 & 0.778 \\
\hline Ethical Climate & 0.681 & 0.688 & 0.862 & 0.757 \\
\hline Firm Level OCB & 0.773 & 0.404 & 0.753 & 0.607 \\
\hline Procedural Justice & 0.793 & 0.807 & 0.863 & 0.612 \\
\hline Top Management Ethical Leader & 0.785 & 0.801 & 0.860 & 0.606 \\
\hline Trust in Organization & 0.838 & 0.842 & 0.885 & 0.608 \\
\hline
\end{tabular}

The above shown table No. 5 clearly shows that variance extracted values are above than 0.5 of all the variables including Distributive Justice (DJ), Ethical Climate (EC), Firm - Level organizational Citizenship Behaviour (OCB), Procedural Justice (PJ), Top management ethical leadership (EL) and Trust in Organization (OT).in addition to that, Cronbach's Alpha values are above than 0.70, except of the ethical climate, which is 0.681 and that is considered reliable according to (Hair, Black, Babin, \& Anderson, 2010). It states that the 0.6 value of reliability is acceptable for an exploratory research but it will be considered as lower value (underestimate). However, it supports convergent validity of instrument.

Discriminant validity:

Discriminate validity can be characterized as any single construct when contrasts from other constructs in the model (Carmines \& Zeller, 1979). Discriminate validity outcomes are acceptable when the constructs' AVE loading is more than 0.5 which implies that minimum $50 \%$ of variance is taken by the construct (Chin, 1998). Discriminate validity is initiated if the factors which are in diagonal are considerably higher than those values in off-diagonal in the parallel columns and rows. 


\section{Macrothink}

Table 6. Discriminant Validity

\begin{tabular}{|c|c|c|c|c|c|c|}
\hline Variables & $\begin{array}{l}\text { Distributive } \\
\text { Justice }\end{array}$ & $\begin{array}{l}\text { Ethical } \\
\text { Climate }\end{array}$ & $\begin{array}{l}\text { Firm Level } \\
\text { OCB }\end{array}$ & $\begin{array}{l}\text { Procedural } \\
\text { Justice }\end{array}$ & $\begin{array}{l}\text { Top } \\
\text { Management } \\
\text { Ethical } \\
\text { Leader }\end{array}$ & $\begin{array}{l}\text { Trust in } \\
\text { Organization }\end{array}$ \\
\hline Distributive Justice & 0.882 & & & & & \\
\hline Ethical Climate & 0.132 & 0.870 & & & & \\
\hline Firm Level OCB & 0.449 & 0.239 & 0.779 & & & \\
\hline Procedural Justice & 0.582 & 0.285 & 0.370 & 0.782 & & \\
\hline $\begin{array}{l}\text { Top Management } \\
\text { Ethical Leader }\end{array}$ & 0.182 & 0.261 & 0.263 & 0.244 & 0.779 & \\
\hline Trust in Organization & 0.716 & 0.281 & 0.469 & 0.619 & 0.271 & 0.780 \\
\hline
\end{tabular}

Hypothesis Testing:

In PLS-SEM, bootstrapping is one of the key stride, which gives the data of constancy of factor guesstimate. Sub-tests are drawn everywhere from the first example including substitution, in this process (Hair, Matthews, Matthews, \& Sarstedt, 2017). Bootstrapping offers the evidence of stability of coefficient estimate. In this procedure, an enormous number of sub-samples are drawn from the original sample with replacement (Hair, Hult, Ringle, \& Sarstedt, 2016). SmartPLS shows the t-values for structural model evaluations got from the bootstrapping process, after running the bootstrap routine. The outcmes of path coefficients for all the hypothesis are revealed in the following table. The t-value greater than $1.96(\mathrm{p}$ $<.005)$ indicates that the relation is significant at 95\% confidence level $(\alpha=0.05)$. Paths demonstrating whether the relationship among measured and latent variables are significant or not. The path diagram showed in figure 2 . 


\section{MInstitute Macrothink}

International Journal of Human Resource Studies ISSN 2162-3058

Table 7. Significant Testing Results of Structural Model Path Coefficients

\begin{tabular}{|c|c|c|c|c|}
\hline Structural Path & Path Coefficient & T Statistics & $\mathrm{P}$ Values & Conclusion \\
\hline Distributive Justice ->Firm Level OCB & 0.354 & 4.430 & 0.000 & Supported \\
\hline Ethical Climate $->$ Distributive Justice & -0.075 & 1.480 & 0.139 & $\begin{array}{l}\text { Not } \\
\text { Supported }\end{array}$ \\
\hline Ethical Climate -> Procedural Justice & 0.121 & 2.207 & 0.027 & Supported \\
\hline Procedural Justice -> Firm Level OCB & 0.164 & 2.085 & 0.037 & Supported \\
\hline $\begin{array}{l}\text { Top Management Ethical Leadership -> } \\
\text { Ethical Climate }\end{array}$ & 0.261 & 3.501 & 0.000 & Supported \\
\hline $\begin{array}{l}\text { Top Management Ethical Leadership -> } \\
\text { Trust in Organization }\end{array}$ & 0.271 & 3.752 & 0.000 & Supported \\
\hline Trust in Organization -> Distributive Justice & 0.737 & 20.355 & 0.000 & Supported \\
\hline Trust in Organization -> Procedural Justice & 0.585 & 11.378 & 0.000 & Supported \\
\hline
\end{tabular}

The above table No. 7 show the path coefficient is 0.354 , which indicates that the independent variable distributive justice (DJ) shows the $35.4 \%$ variation in the dependent variable that is Firm - Level organizational Citizenship Behaviour (OCB) of employees at each level of organization in various sectors operative in Pakistan. The variation produced in dependent variable Firm - Level organizational Citizenship Behaviour (OCB) is significant owing to the t-value $4.430>1.96$ and $\mathrm{p}$ value $0.000<0.05$. Hence the hypothesis that Distributive Justice (DJ) has significant relationship with Firm- level OCB can be accepted.

The path coefficient is -0.075 , which indicates that the independent variable Ethical Climate (EC) shows the $-7.5 \%$ variation in the dependent variable that is Distributive Justice (DJ) of employees at each level of organization in various sectors operative in Pakistan. The variation produced in dependent variable Distributive Justice (DJ) is significant owing to the t-value $1.480<1.96$ and $\mathrm{p}$ value $0.139>0.05$. Hence, the hypothesis Ethical climate has significant relationship with distributive justice can be rejected.

Path coefficient is 0.121 , which indicates that the independent variable that is Ethical Climate (EC) shows the $12.1 \%$ variation in the dependent variable that is Procedural Justice (PJ) of employees at each level of organization in various sectors operative in Pakistan. The variation produced in dependent variable Procedural Justice $(\mathrm{PJ})$ is significant owing to the $t$-value $2.207>1.96$ and $\mathrm{p}$ value $0.027<0.05$. Hence the hypothesis that Ethical climate has 
significant relationship with procedural justice climate can be accepted.

Path coefficient is 0.164 , which indicates that the independent variable that is Procedural Justice (PJ) shows the $16.4 \%$ variation in the dependent variable that is Firm - Level organizational Citizenship Behaviour (OCB) of employees at each level of organization in various sectors operative in Pakistan. The variation produced in dependent variable Firm Level organizational Citizenship Behaviour (OCB) is significant owing to the t-value $2.085>$ 1.96 and $\mathrm{p}$ value $0.037<0.05$. Hence the hypothesis that Procedural justice climate has significant relationship with firm level OCB can be accepted.

Path coefficient is 0.261 , which indicates that the independent variable that is Top Management Ethical Leadership (EL) shows the 26.1\% variation in the dependent variable that is Ethical Climate (EC) of employees at each level of organization in various sectors operative in Pakistan. The variation produced in dependent variable Ethical Climate (EC) is significant owing to the $\mathrm{t}$-value $3.501>1.96$ and $\mathrm{p}$ value $0.000<0.05$. Hence the hypothesis that Top management ethical leadership is positively related to ethical climate can be accepted.

Path coefficient is 0.271 , which indicates that the independent variable that is Top Management Ethical Leadership (EL) shows the $27.1 \%$ variation in the dependent variable that is Trust in Organisation (OT) of employees at each level of organization in various sectors operative in Pakistan. The variation produced in dependent variable Trust in Organisation (OT) is significant owing to the t-value $3.752>1.96$ and p value $0.000<0.05$. Hence the hypothesis that Top management ethical leadership is positively related to trust in organization can be accepted.

Path coefficient is 0.737 , which indicates that the independent variable that is Trust in Organisation (OT) shows the $73.7 \%$ variation in the dependent variable that is Distributive Justice (DJ) of employees at each level of organization in various sectors operative in Pakistan. The variation produced in dependent variable Distributive Justice (DJ) is significant owing to the $t$-value $20.355>1.96$ and $p$ value $0.000<0.05$. Hence the hypothesis that Trust in organization has significant relationship with distributive justice can be accepted.

Path coefficient is 0.585 , which indicates that the independent variable that is Trust in Organisation (OT) shows the $58.5 \%$ variation in the dependent variable that is Procedural Justice (PJ) of employees at each level of organization in various sectors operative in Pakistan. The variation produced in dependent variable Procedural Justice (PJ) is significant owing to the t-value $11.387>1.96$ and $\mathrm{p}$ value $0.000<0.05$. Hence the hypothesis that Trust in organization has significant relationship with procedural justice can be accepted. 


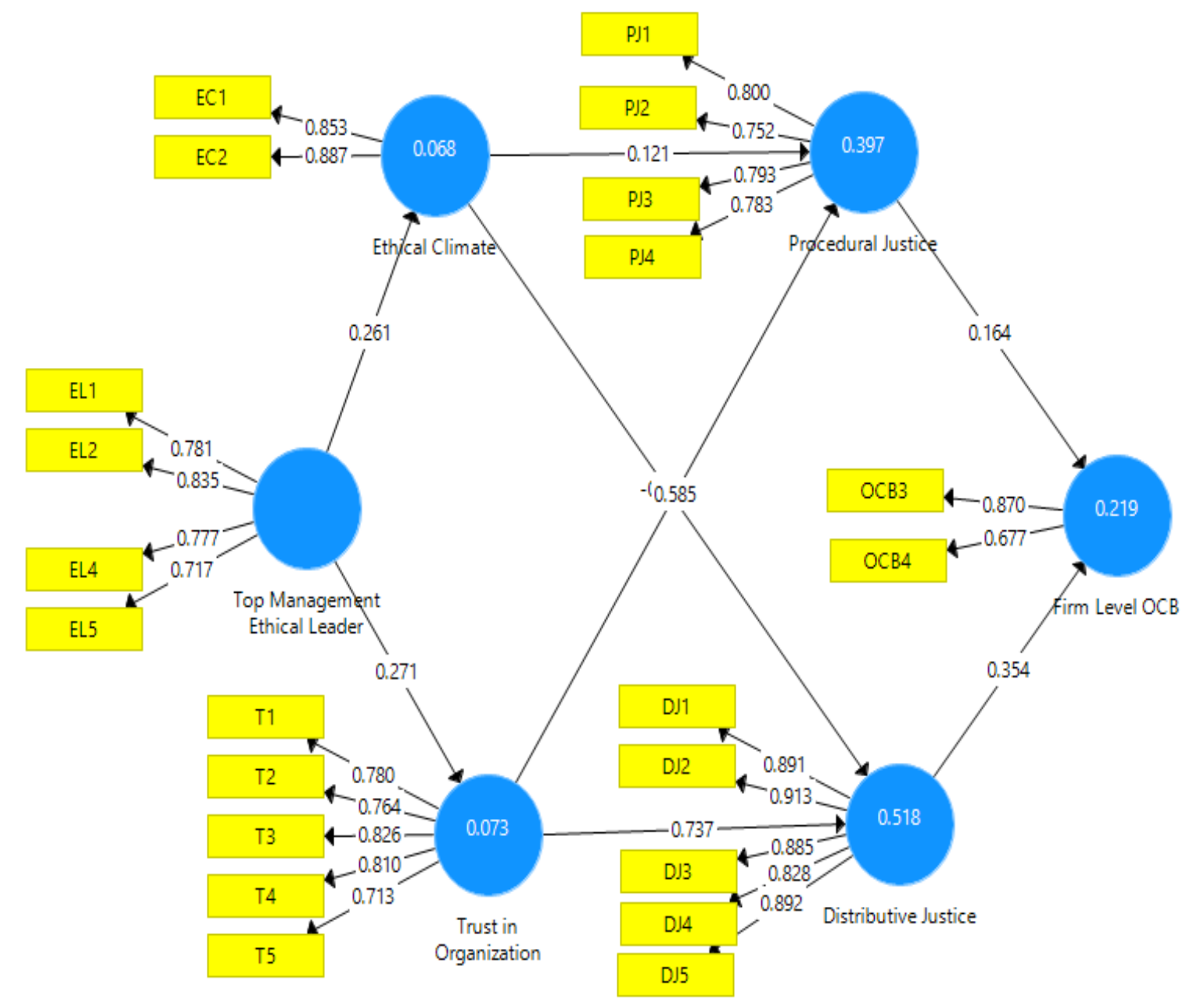

\section{Discussions}

The aim of the present study was to examine the impact of top management ethical leadership on firm level organizational citizenship behavior (OCB) mediating effect of ethical climate, trust in organization and justice. Data was collected from 210 employees working in different sectors operative in Pakistan. The total of 8 hypotheses were tested in this study all of them

were direct hypothesis. The first hypothesis of the present study was top management ethical leadership is positively related to ethical climate. The results of the study fully supported the hypothesis that there is positive relation between top management ethical leadership and ethical climate. The second hypothesis of the present research study was that top management ethical leadership is positively related to trust in organization. The results of the research study fully supported the hypothesis hence it can be said that top management ethical

leadership has positive relation with trust in organization. The third hypothesis of the study was that ethical climate has significant relationship with procedural justice climate and the results also showed the same positive relation of ethical climate and procedural justice. Furthermore, the fourth hypothesis of the present study was that ethical climate has significant relationship with distributive justice. The results of the research do not support the fourth hypothesis which means there is no positive relation between ethical climate and 
distributive justice. In addition, the fifth hypothesis of this study was that trust in organization has significant relationship with distributive justice. The research results supported the hypothesis that there is a positive relation between trust in organization and distributive justice. The sixth hypothesis trust in organization has significant relationship with procedural justice climate was also supported by the results of the study. The seventh hypothesis procedural justice climate has significant relationship with firm level OCB was also supported by the results and the last hypothesis distributive justice climate has significant relationship with firm level OCB was also supported by the results of the present study. In short all the hypothesis except the fourth one are supported by the results of the study. The data was collected through the non-probability sampling techniques. Descriptive statistic is used to analyse the responses of the questionnaire. Confirmatory factor analysis (CFA) and structural equation modelling (SEM) were used for inference.

\section{Conclusion}

This study analysed how Top Management Ethical Leadership Influence Organization Citizenship Behaviour (OCB). We proposed that Ethical leadership affects OCB by promoting ethical climate and Trust in Organization. Then these factors give rise to Procedural Justice Climate and Distributive Justice, which then results in OCB. This theoretical framework was empirically tested by gathering data of 210 employees working in various sectors operative in Pakistan by means of close ended Likert scale type questionnaires. Numerous statistical techniques for instance descriptive statistics, confirmatory factor analysis (CFA) and structural equation modelling (SEM) were utilized for analysis of the results. As proposed in our theory, the results indicated a positive impact of Top Management Ethical Leadership on Ethical Climate \& Trust in Organization. Moreover, a significant positive impact of trust in organization on both Procedural Justice Climate \& Distributive Justice. Furthermore, both of these fully mediates the effects of top management ethical leadership on organizational citizenship behaviour. From a different angle, the impact of ethical climate on Procedural Justice Climate is significantly positive. However, the relationship between ethical climate and Distributive Justice was found to be insignificant. This paper aims to fill the gap of study by (Shin, Sung, Choi, \& Kim, 2014) (Xu, Loi, \& Ngo, 2014) where the research was conducted on two separate models and these studies were done in Korea and China, therefore their result cannot be considered as generalized and implementable in Pakistan. The study has investigated various sectors operative in Pakistan. The investigation provides a diversified demographic environment for the research so the conclusions can be implemented in various settings. The constraints of the previously mentioned investigations incorporates the appraisal of moral administration of top administration was done by top administration's heads' self-provides details regarding good perspectives and behaviours. In like manner, the firm-level Organizational Citizenship Behaviour (OCB) was assessed using the accumulation of delegate evaluations of individual level OCB. These measures could invite biasness, for instance, social engaging quality. This gap is secured by gathering the information from overall representatives working in various divisions operative in Pakistan, be it top supervisor, centre administrator, lower manager or non-manager. Through this an unmistakable and genuine portrayal of populace and solid 
information is gathered.

As stated, the Top Management Ethical Leadership has significant relationship with Ethical Climate (EL) and Trust in Organization (OT), thus top managers of the corporations should act in an ethical manner in order to enhance the climate of the corporation in an ethical and positive way and to increase the trust of employees in the organization which will eventually leads towards increased Firm Level OCB. In addition, the corporations should have enhanced Ethical Climate (EC) in order to pursue Procedural Justice Climate (PJ) and Distributive Justice (DJ) in the corporation. Because as indicate by the result of the present study, the Procedural Justice Climate (PJ) and Distributive Climate (DJ) has significant impact on Firm Level Organizational Citizenship Behaviour (OCB).

It is also suggested that the organizational heads should understand the importance and effectiveness of ethical leadership. Because ethical leadership plays the major and leading role for creating ethical climate in the organization and for developing employees' trust in organization. Which in return creates better understanding and relationship between employees, trust on each other, as well as eagerness towards helping and showing concern for the colleagues or peers in need. When organizations get success on above mentioned concepts they eventually get success in achieving their employees' trust, their stability, growth in market, goodwill and hence they become employer of choice.

Justice climate should also be enforced in the organizations for the better employees' organisational citizenship behaviour and for increased both tangible and intangible benefits of the organisation.

\section{References}

Bal, P. M., De Lange, A. H., Ybema, J. F., Jansen, P. G., \& Van Der Velde, M. E. (2011). Age and trust as moderators in the relation between procedural justice and turnover: A large-scale longitudinal study. Applied Psychology: An International Review, 66-86. https://doi.org/10.1111/j.1464-0597.2010.00427.x

Blau, P. M. (1964). Exchange and power in social life. New York: Wiley.

Brown, M. E., \& Mitchell, M. S. (2010). Ethical and unethical leadership: Exploring new avenues for future research. Business Ethics Quarterly, 583-616. https://doi.org/10.5840/beq201020439

Brown, M. E., \& Treviño, L. K. (2006). Ethical leadership: A review and future directions. The Leadership Quarterly, 595-616. https://doi.org/10.1016/j.leaqua.2006.10.004

Brown, M. E., Treviño, L. K., \& Harrison, D. A. (2005). Ethical leadership: A social learning perspective for construct development and testing. Organizational Behavior and Human Decision Processes, 117-134. https://doi.org/10.1016/j.obhdp.2005.03.002

Carlson, D. S., \& Perrewe, P. L. (1995). Institutionalization of organizational ethics through transformational leadership. Journal of Business Ethics, 829-838. https://doi.org/10.1007/BF00872349 


\section{Macrothink}

International Journal of Human Resource Studies ISSN 2162-3058 2020, Vol. 10, No. 1

Carmines, E. G., \& Zeller, R. A. (1979). Reliability and Validity Assessment, 17. California: Sage. https://doi.org/10.4135/9781412985642

Chin, W. W. (1998). The Partial Least Square Approach to Structural Equation Modelling, 295-336.

Choi, J. N., \& Chang, J. Y. (2009). Innovation Implementation in the Public Sector: An Integration of Institutional and Collective Dynamics. Journal of Applied Psychology, 245-253. https://doi.org/10.1037/a0012994

Cook, J., \& Wall, T. (1980). New work attitude measure of trust, organizational commitment and personal need non-fulfillment. Journal of Occupational Psychology, 39-52. https://doi.org/10.1111/j.2044-8325.1980.tb00005.x

Cropanzano, R., Goldman, B., \& Folger, R. (2003). Deontic justice: The role of moral principles in workplace fairness. Journal of Organizational Behavior, 1019-1024. https://doi.org/10.1002/job.228

Dickson, M. W., Smith, B., Grojean, M. W., \& Ehrhart, M. G. (2001). An Organizational Climate Regarding Ethics: The Outcome of Leader Values and the Practices That Reflect Them. The Leadership Quarterly, 197-217. https://doi.org/10.1016/S1048-9843(01)00069-8

Ehrhart, M. G. (2004). Leadership and procedural justice climate as antecedents of unit-level organizational citizenship behavior. Personnel Psychology, 61-94. https://doi.org/10.1111/j.1744-6570.2004.tb02484.x

Eisenberger, R., Karagonlar, G. K., Stinglhamber, F., Neves, P., Becker, T. E., \& Gonzales-Morales, M. G. (2010). Leader-member exchange and affective organizational commitment:The contribution of supervisor's organizational embodiment. Journal of Applied Psychology, 1085-1103. https://doi.org/10.1037/a0020858

Ferrin, D. L., \& Dirks, K. T. (2002). Trust in Leadership: Meta-Analytic Findings and Implications for Research and Practice. Journal of Applied Psychology, 611-628. https://doi.org/10.1037//0021-9010.87.4.611

Freeman, R. E., Gilbert, D. J., \& Hartman, E. (1988). Values and the foundations of strategic management. Journal of business ethics, 821-835. https://doi.org/10.1007/BF00383045

Gong, Y., Chang, S., \& Cheung, S. Y. (2010). High performance work system and collective OCB: A collective social exchange perspective. Human Resource Management Journal, 119-137. https://doi.org/10.1111/j.1748-8583.2010.00123.x

Hair, J. F., Black, W. C., Babin, B. J., \& Anderson, R. E. (2010). Multivariate Data Analysis, 7th Edition. Pearson.

Hair, J. F., Matthews, L. M., Matthews, R. M., \& Sarstedt, M. (2017). PLS-SEM or CB-SEM: updated guidelines on which method to use. Int. J. Multivariate Data Analysis, 107-123. Retrieved from https://www.google.com/url?sa=t\&rct=j\&q=\&esrc=s\&source=web\&cd=1\&cad=rja\&uact=8 
\&ved=2ahUKEwj8mJ316LTiAhWBxIsKHbO2ApsQFjAAegQIBxAC\&url=https\%3A\%2F\% 2Fwww.researchgate.net\%2Fprofile\%2FThien_Sang_Lim\%2Fpost\%2FWhat_papers_or_ma nuals_do_you_recommend_the_most_to

Hoy, W. K., Hoy, W. K., \& Tarter, C. J. (2004). Organizational justice in schools:No justice without trust. International Journal of Educational Management, 250-259. https://doi.org/10.1108/09513540410538831

Kalshoven, K., Den Hartog, D. N., \& De Hoogh, A. H. (2012). Ethical leadership and followers' helping and initiative: The role of demonstrated responsibility and job autonomy. European Journal of Work and Organizational Psychology, 1-30.

Kaptein, M. (2019). The Moral Entrepreneur: A New Component of Ethical Leadership. Journal of Business Ethics, 1135-1150. https://doi.org/10.1007/s10551-017-3641-0

Lin, X., Che, H., \& Leung, K. (2009). The role of leader morality in the interaction effect of procedural justice and outcome favorability. Journal of Applied Social Psychology, 1536-1561. https://doi.org/10.1111/j.1559-1816.2009.00494.x

Lind, E. A. (2001). Fairness heuristic theory: Justice judgments as. In J. Greenberg, \& R. Cropanzano, Advances in organizational justice, 56-88. Stanford, CA: Stanford University Press.

Lind, E. A., Tyler, T. R., \& Huo, Y. J. (1997). Procedural context and culture: Variation in the antecedents of procedural justice judgments. Journal of Personality and Social Psychology, 767-780. https://doi.org/10.1037/0022-3514.73.4.767

Loi, R., Lam, L. W., \& Chan, K. W. (2012). Coping with Job Insecurity: The Role of Procedural Justice, Ethical Leadership and Power Distance Orientation. Journal of Business Ethics, 361-372. https://doi.org/10.1007/s10551-011-1095-3

Luria, G., \& Yagil, D. (2008). Procedural justice, ethical climate and service outcomes in restaurants. International Journal of Hospitality Management, 276-283. https://doi.org/10.1016/j.ijhm.2007.07.022

Mayer, D. M., Kuenzi, M., Greenbaum, R., Bardes, M., \& Salvador, R. B. (2009). How low does ethical leadership flow? Test of a tickle-down model. Organizational Behavior and Human Decision Processes, 1-13. https://doi.org/10.1016/j.obhdp.2008.04.002

Michael, E., \& Brown, L. K. ( 2005). Ethical leadership: A social learning perspective for construct development and testing. Organizational Behavior and Human Decision Processes, 117-134. https://doi.org/10.1016/j.obhdp.2005.03.002

Moorman, R. H. (1991). Relationship Between Organizational Justice and Organizational Citizenship Behaviors: Do Fairness Perceptions Influence Employee Citizenship? Journal of Applied Psychology, 845-855. https://doi.org/10.1037//0021-9010.76.6.845 


\section{Macrothink}

International Journal of Human Resource Studies ISSN 2162-3058 2020, Vol. 10, No. 1

Mulki, J. P., Jaramillo, J. F., \& Locander, W. B. (2009). Critical Role of Leadership on Ethical Climate and Salesperson Behaviors. Journal of Business Ethics, 125-141. https://doi.org/10.1007/s10551-008-9839-4

Naumann, S. E., \& Bennett, N. (2000). A case for procedural justice climate: Development and test of a multilevel model. Academy of Management Journal, 881-889. https://doi.org/10.2307/1556416

Neubert, M. J. (2009). The virtuous influence of ethical leadership behavior: Evidence from the field. Journal of Business Ethics, 157-170. https://doi.org/10.1007/s10551-009-0037-9

Pagliaro, S., Presti, A. L., Barattucci, M., Giannella, V. A., \& Barreto, M. (2018). On the Effects of Ethical Climate(s) on Employees' Behavior: A Social Identity Approach. Frontiers in Psychology, 1-10. https://doi.org/10.3389/fpsyg.2018.00960

Pastoriza, D., Ariño, M. A., \& Ricart, J. E. (2007). Ethical managerial behavior as an antecedent of organizational social capital. Journal of Business Ethics, 329-341. https://doi.org/10.1007/s10551-006-9334-8

Pillai, R., Schriesheim, C. A., \& Williams, E. S. (1999). Fairness perceptions and trust as mediators for transformational and transactional leadership: A two-sample study. Journal of Management, 897-933. https://doi.org/10.1177/014920639902500606

Posner, B. Z., \& Schmidt, W. H. (1992). Values and the American Manager: An Update Updated. California Management Review, 80-94. https://doi.org/10.2307/41167425

Premeaux, S. (2009). The Link Between Management Behavior and Ethical Philosophy in the Wake of the Enron Convictions. Journal of Business Ethics, 13-25. https://doi.org/10.1007/s10551-008-9745-9

Rawls, J. (1971). A theory of justice. Cambridge, MA: Belknap Press of Harvard University Press.

Robinson, S. L. (1996). Trust and Breach of the Psychological Contract. Administrative Science Quarterly, 574-599. https://doi.org/10.2307/2393868

Robinson, S. L., \& Rousseau, D. M. (1994). Violating the psychological contract: Not the exception but the norm. Journal of Organizational Behavior, 245-259. https://doi.org/10.1002/job.4030150306

Schminke, M., Ambrose, M., \& Neubaum, D. O. (2005). The Effect of Leader Moral Development on Ethical Climate and Employee Attitudes. Organizational Behavior and Human Decision Processes, 135-151. https://doi.org/10.1016/j.obhdp.2005.03.006

Scott, W. R. (1995). Institutions and organizations. Thousand Oaks, CA: Sage.

Sert, A., Elçi, M., Uslu, T., \& Şener, İ. (2014). The Effects of Organizational Justice and Ethical Climate on Perceived Work Related Stress. Procedia Social and Behavioral Sciences, 1187-1198. https://doi.org/10.1016/j.sbspro.2014.09.134 
Shin, \& Yuhyung. (2012). CEO Ethical Leadership, Ethical Climate, Climate Strength, and Collective Organizational Citizenship. Journal of Business Ethics, 299-312. https://doi.org/10.1007/s10551-011-1091-7

Shin, Y., Sung, S. Y., Choi, J. N., \& Kim, M. S. (2014). Top Management Ethical Leadership and Firm Performance: Mediating Role of Ethical and Procedural Justice Climate. Journal of Business Ethics, 43-57. https://doi.org/10.1007/s10551-014-2144-5

Singh, U., \& Srivastava, K. B. (2016). Organizational Trust and Organizational Citizenship Behaviour. Global Business Review, 595-609. https://doi.org/10.1177/0972150916630804

Song, J. H., Kang, I. G., Shin, Y. H., \& Kim, H. K. (2012). The Impact of an Organization's Procedural Justice and Transformational Leadership on Employees' Citizenship Behaviors in the Korean Business Context. Journal of Leadership \& Organizational Studies, 424-436. https://doi.org/10.1177/1548051812446659

Tang, T. L. P., \& Sarsfield-Baldwin, L. J. (1996). Distributive and Procedural Justice as Related to Satisfaction and Commitment. Houston, TX: Southwestern Psychological Association.

Treviño, L. K., \& Weaver, G. R. (2001). Organizational justice and ethics program "follow-through": Influences on employees' harmful and helpful behavior. Business Ethics Quarterly, 651-671. https://doi.org/10.2307/3857765

Treviño, L. K., Brown, M., \& Hartman, L. P. (2003). A qualitative investigation of perceived executive ethical leadership: Perceptions from inside and outside the executive suite. Human Relations, 5-37. https://doi.org/10.1177/0018726703056001448

Treviño, L. K., Butterfield, K. D., \& McCabe, D. L. (1998). The ethical context in organizations: Influences on employee attitudes and behaviour. Business Ethics Quarterly, 447-476. https://doi.org/10.2307/3857431

Tyler, T. R. (1994). Psychological models of the justice motive: Antecedents of distributive and procedural justice. Journal of Personality and Social Psychology, 850-863. https://doi.org/10.1037/0022-3514.67.5.850

Tyler, T. R., \& Blader, S. L. (2003). The group engagement model: Procedural justice, social identity, and cooperative behavior. Personality and Social Psychology Review, 349-361. https://doi.org/10.1207/S15327957PSPR0704_07

Vuuren, H. V., Dhurup, M., \& Joubert, P. (2016). Justice In The Workplace: The Influence Of Procedural, Distributive And Interactional Justice On Organisational Citizenship Behaviour Among Employees In The Police Service. International Journal Of Economics And Finance Studies, 177-191.

Walumbwa, F. O., \& Schaubroeck, J. (2009). Leader Personality Traits and Employee Voice Behavior: Mediating Roles of Ethical Leadership and Work Group Psychological Safety. Journal of Applied Psychology, 1275-1286. https://doi.org/10.1037/a0015848 


\section{Macrothink}

International Journal of Human Resource Studies

ISSN 2162-3058 2020, Vol. 10, No. 1

Walumbwa, F. O., Hartnell, C. A., \& Oke, A. (2010). Servant Leadership, Procedural Justice Climate, Service Climate,Employee Attitudes, and Organizational Citizenship Behavior:A Cross-Level Investigation. Journal of Applied Psychology, 517-529. https://doi.org/10.1037/a0018867

Whitener, E. M., Brodt, S. E., Korsgaard, M. A., \& Werner, J. M. (1998). Managers as initiators of trust: An exchange relationship framework for understanding managerial trustworthy behavior. Academy of Management Journal, 513-530. https://doi.org/10.5465/amr.1998.926624

Wong, Y. T., Wong, C. S., \& Ngo, H. Y. (2012). The effects of trust in organisation and perceived organisational support on organisational citizenship behaviour: a test of three competing models. The International Journal of Human Resource Management, 278-293. https://doi.org/10.1080/09585192.2011.610966

Xu, A. J., Loi, R., \& Ngo, H. Y. (2014). Ethical Leadership Behavior and Employee Justice Perceptions: The Mediating Role of Trust in Organization. Journal of Business Ethics, 493-504. https://doi.org/10.1007/s10551-014-2457-4

Yener, M., Yaldiran, M., \& Ergun, S. (2012). The Effect Of Ethical Climate On Work Engagement. Procedia Social and Behavioral Sciences, 724-733. https://doi.org/10.1016/j.sbspro.2012.09.1050

Zikmund, W. G., Babin, B. J., Carr, J. C., \& Griffin, M. (2012, 12 03). Cengage learning US. Retrieved from cengage.com.au: https://cengage.com.au/product/title/business-research-methods/isbn/9781111826925

\section{Copyright Disclaimer}

Copyright for this article is retained by the author(s), with first publication rights granted to the journal.

This is an open-access article distributed under the terms and conditions of the Creative Commons Attribution license (http://creativecommons.org/licenses/by/4.0/). 